\title{
Morphological diversity and the cultivation practice of Abelmoschus manihot in West Papua, Indonesia
}

\author{
SARASWATI PRABAWARDANI ${ }^{1, \vartheta}$, IRNANDA A.F. DJUUNA ${ }^{1}$, FENNY ASYEREM ${ }^{1}$, ALEXANDER YAKU ${ }^{1}$, \\ GRAHAM LYONS ${ }^{2}$ \\ ${ }^{1}$ Faculty of Agriculture, Universitas Negeri Papua. Jl. Gunung Salju, Manokwari 98314, Papua Barat, Indonesia. Tel.: +62-986-211430, Fax: +62-986-211455, \\ "email: s.prabawardani@unipa.ac.id, danysaraswati@gmail.com \\ ${ }^{2}$ School of Agriculture, Food and Wine, Waite Campus, The University of Adelaide, PMB 1, Glen Osmond SA 5064, Australia.
}

Manuscript received: 5 October 2015. Revision accepted: 27 October 2016.

\begin{abstract}
Prabawardani S, Djuuna IAF, Asyerem F, Yaku A, Lyons G. 2016. Morphological diversity and the cultivation practice of Abelmoschus manihot in West Papua, Indonesia. Biodiversitas 17: 894-999. Papua is considered to be the second diversity centre of this plant; however, its diversity is declining, due to habitat destruction for regional development or land fragmentation, and hence Aibika preservation is a priority. This study aimed to assess the status of Aibika (Abelmoschus manihot L. Medik) diversity by collecting, preserving, conducting Aibika morphological characterization and preliminary assessment of its cultivation technique. Diverse germplasm can then be used to improve Aibika. The study was conducted between April and June 2015 in Mandopi, Warmare, Prafi of Manokwari Regency and Minyambouw of Arfak Mountain Regency. Descriptive method was used in this study, and the relationships among cultivars were analyzed according to Cluster Analysis using Excel Stat. Phenotypes, comprising 29 morphological characters, were recorded for cluster analysis. There were 39 Aibika cultivars collected from 4 locations of West Papua. Based on the UPGMA dendrogram, it was revealed that two primary clusters (A and B) separating separate the cultivars. Cluster A clearly separated from Cluster B at a dissimilarity value of about $0.57(57 \%)$. Around $3.3(33 \%)$ of variance separated the cultivars into four groups, consisting of cluster A, B1, B2, B3. Cluster A (MAD-01, Man-9, Man-11, Minyam-03, Imbenti-02, SP-02) is the most diverse area which consisted of cultivars of three different clusters. In Papua, Aibika is cultivated in a traditional mixed-cropping system, without appropriate planting distance, fertilizer, and pesticide application. This has resulted in suboptimal growth and high susceptibility to pests.
\end{abstract}

Keywords: Abelmoschus manihot, aibika, diversity, gedi, leafy vegetable, morphology

\section{INTRODUCTION}

Papua is known to have enormous crop diversity; however, there has been a lack of scientific study in this area. Among the biodiversity that has received little attention is Aibika or Gedi in the Indonesian language. Aibika is a tropical perennial shrub and belongs to the family Malvaceae. This plant originated in China, then spread through India, Papua, South Pacific Islands, and northern Australia (Zeven and Zhudwosky 1980). The greatest diversity is found in Papua New Guinea, the Solomon Islands and Vanuatu (Kambuou et al. 2003). The plants show great variability in leaf shape and size, petiole and stem colour, branching, and flowering characteristics. Therefore, the island of Papua is estimated to have a wide variety of this plant. Most Papuan food gardens are planted with some Aibika cultivars, which can be distinguished by leaf shape and petiole colour differences.

Aibika is among the popular leafy vegetables consumed by Papuan people and communities in other eastern parts of Indonesia. The edible part of Aibika is the young shoot tip or succulent young leaves. It is cultivated extensively and throughout the year in some Melanesian countries for its highly nutritious leaves and shoots tips (Kambuou et al. 2003). Aibika is reported to contain high nutrients; especially protein and micronutrients (Westwood and Kesavan 1982; Yalambing et al. 2015). Nutritionist (Susan
Parkinson) in her personal communication with Westwood and Kesavan (1982) suggested that every household in the South Pacific region cultivate this plant. This plant is also used as a traditional medicine by indigenous people throughout the island of Papua and the Pacific Islands region, for relieving kidney pain, reducing high cholesterol, treating pregnant women to ease childbirth, stimulating lactation, treating diarrhea, and protecting against osteoporosis. Because of the secondary metabolites present in the plant, particularly antioxidants, it is efficacious to contribute contributing to the prevention of some diseases (Hodgson et al. 2006; Puel et al. 2005; Goebel et al. 2010).

In some parts of India, Aibika is used as a source of traditional medicine for kidney pain, heartburn, high cholesterol, osteoporosis, as well as to induce labour in pregnant women (Todarwal, et al. 2011). The flowers of $A$. manihot have been used as a traditional Chinese medicine for the treatment of chronic renal disease and diabetic nephropathy (An et al. 2011). Aibika has drawn much attention recently due to its potential beneficial health effects. Studies on Aibika have led to the isolation of two main kinds of plant secondary metabolites, flavonoids, and alkaloids. Aibika contains quercetin-3-O-robinoside, hyperin, Isoquercetin, gossipetin-8-O-glucuronide, and myricetin (Liu et al. 2006). The flowers contain quercetin3-robinoside, quercetin-3'-glycosides, hyperin, myrecetin, anthocyanins, and hyperoside. Leaves of Aibika when 
tested, have been shown to prevent ovariectomy-induced femoral ostopenia (condition of bone mineral density lower than normal range in the joints limbs as a result of surgical removal of the uterus/ ovaries) (Lin-lin et al. 2007; Jain et al. 2009). Aibika can also improve the function of glomerular filtration, reduced proteinuria, hyperplasia messangium which can reduce the damage of kidney tissue (Shao-Yuetal., 2006). Flavonoids in Aibika have many important functions for health, including reducing the risk of cardiovascular disease, hypertension, atherosclerosis, and as an antioxidant (Hodgson et al., 2006), and it is an important cash crop in local markets in Melanesia (Preston 1998).

According to Westwood and Kesavan (1982), Aibika is a highly productive plant vegetable which is highly adapted to the lowlands up to an altitude of $800 \mathrm{~m}$ height above sea level. It is also cultivated in higher altitude areas above $2000 \mathrm{~m}$ with annual rainfall of more than $2000 \mathrm{~mm}$ (Paofa and Kambuou, 2006). Aibika grows throughout the year and provides a continuous supply of highly nutritious leaves and shoot tips. Karafir and Vokames (2003) reported that there are 7 cultivars of Aibika in Nimboran district and 6 cultivars in Kemtuk district of Papua. This diversity can be seen from the shape and size of the leaf, petiole and stem colour, branching and flower characters. However, the diversity of Aibika is reported to be decline in recent years, probably due to rapid development, land fragmentation and global climate change (Kayadu 2013). Comprehensive studies on Aibika need to be done, as research on this plant is still limited.

The objective of the study was to observe the morphological diversity of Aibika through exploration, identification and collection. This study is expected to enrich the understanding of the diversity of Aibika and prevent the loss of the genetic base of this plant. The research also aimed to assess the cultivation techniques applied on Aibika by the local farmers.

\section{MATERIALS AND METHODS}

Exploration of Aibika was carried out from May to June 2015 in the lowland areas of Mandopi, Warmare, Prafi and the highland areas of Arfak (Minyambouw), West Papua, Indonesia (Figure 1) as supply of Aibika in the markets is from these areas. Exploration in each of these areas of known distribution was done to collect all cultivars of Aibika.

The descriptive method with a direct observation technique was applied in this research. Additionally, interviews with residents and local tribe leaders were conducted to determine the cultivars of Aibika, local names and cultivation of Aibika. Traditional Aibika cultivation methods (including land preparation, planting, and maintenance) were recorded.

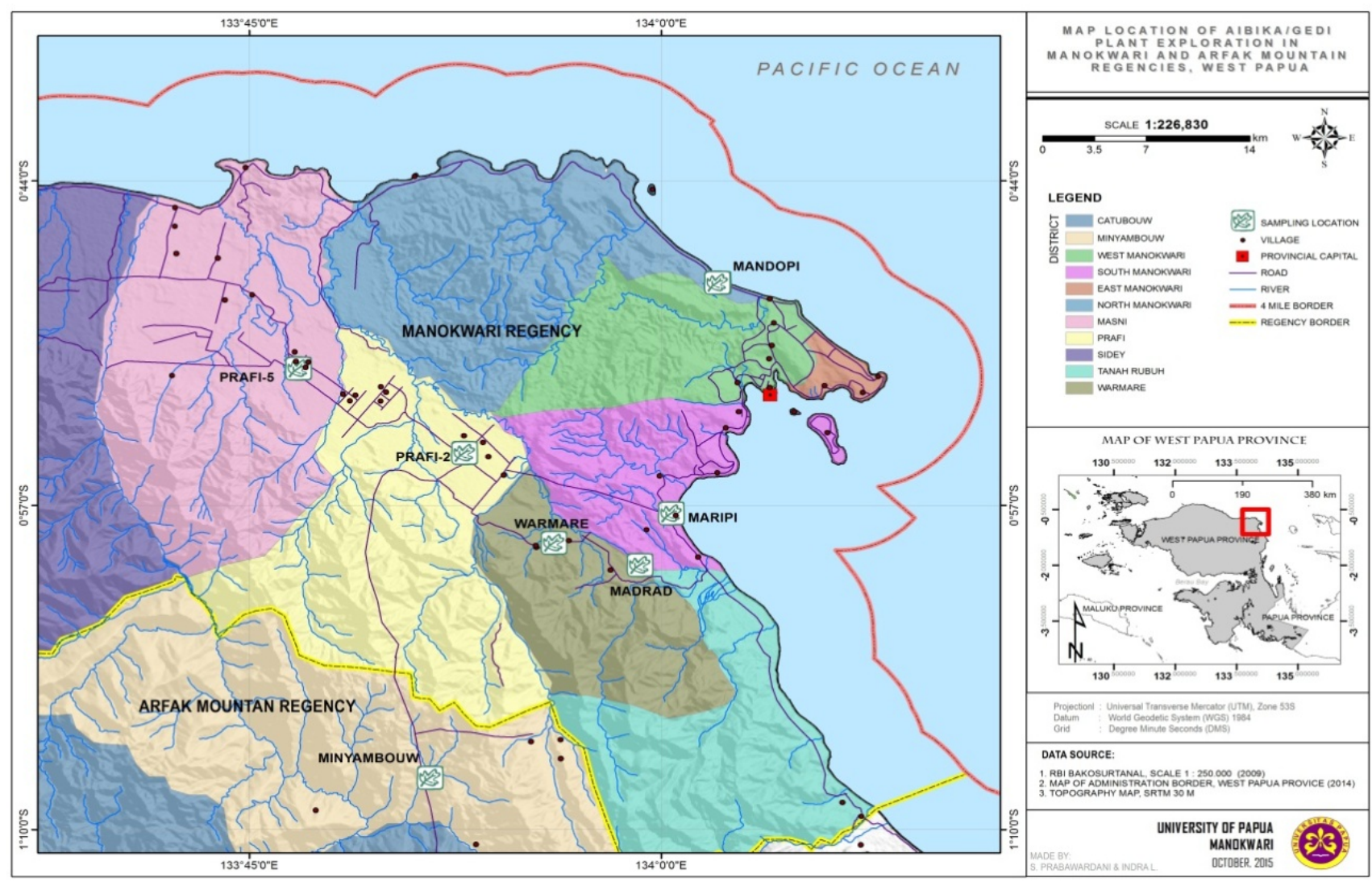

Figure 1. Map of exploration sites of Aibika in Mandopi, Warmare, Prafi (lowland areas of Manokwari) and Minyambouw (Highland area of Arfak), West Papua, Indonesia 
Characterization was performed in the field at each location. The identification of Aibika was based on morphological characters, using descriptor list by Kambuou et al. (2003). The morphological characters of Aibika consisted of stem (pith, hairiness, internode length, diameter, primary stem colour, secondary stem colour, stem pigmentation, branch number); leaf (leaf shape, leaf segment shape, margin, leaf tip, leaf base, leaf shape variability, leaf lustre, leaf vein colour, petiole colour, petiole length. However, no flowers were observed, due to frequent pruning. Morphological characters were taken from Aibika plant samples which aged from 6 to 9 months (plants were still in productive age).

The collected cultivars were taken from farmer's gardens for the purpose of ex-situ collection or preservation in the experimental field of the Agriculture Faculty, the University of Papua, Manokwari. Data on the morphological diversity were analyzed using Unweighted Pair Group Method with Arithmetic UPGMA method using Excel stat program.

\section{RESULTS AND DISCUSSION}

\section{Morphological diversity of Aibika}

During the exploration, 36 Aibika cultivars were collected from 4 locations. The location I was Mandopi where 16 cultivars were found, denoted Man-01 - 16. Location II was Warmare, where 9 Aibika cultivars were collected, namely MARI-01 - 05, MAD-01 - 04. Location III was the transmigration area of Prafi, where five cultivars were found, namely SP1-01 - 03, SP5-01 - 02. Location IV was the highland area of Arfak (Minyambouw), where six cultivars were collected; Imbenti-01, Imbenti-02, Minyambouw-01, Minyambouw02, Minyambouw-03, Ungga-01.

Based on the identification at 4 locations, the diversity of the morphological characters of Aibika was not only revealed to the individual among different locations (among population), but it was also observed in individuals at the same locations (within the population).

The magnitude of morphological characters within the population and between Aibika populations was perceived based on similarity or dissimilarity levels of morphological characters using cluster analysis with Unweighted Pair Group Method with Arithmetic (UPGMA). Based on this method, individuals, or population that have similar morphological characters were collectively or closely clustered. The cluster pattern of individuals or population is based on the similarity matrix, which is described by dendrogram with the character's dissimilarity distance lay between $0.00(0 \%)$ and $1.00(100 \%)$.

The UPGMA dendrogram resulting from the fusion matrix based on dissimilarity model revealed two primary clusters (A and B) separating the cultivars (Figure 1). It is evident that Cluster A (Mad-01, Man-09, Man-11Minyam-03, Imbenti-02, SP1-020 clearly separated from
Cluster B at a dissimilarity value of about 0.57 (57\%). Around 3.3 (33\%) of variance separated the cultivars into four groups, consisting of cluster A, B1, B2, B3. However, if $0.2(20 \%)$ dissimilarity was used to distinguish the cultivars, eight groups were recognized. The groups were A1, A2, A3, B1a, B1b, B2, B3a and B3b. The members of Cluster A were the most widely distributed cultivars which can be found in all locations including I, II, III, and IV. The cultivars of cluster B3 were spread out in three locations (II, III, IV). Meanwhile, the cultivars of cluster B1 only grow in location I. It also can be noted that location IV is the most diverse area which consisted of cultivars of three different clusters which were Imbenti-02, Minyambouw-03 (cluster A), Minyambouw-01, Minyambou-02 and Ungga01 (cluster B2), and Imbenti-01 (cluster B3). The diversity of Aibika occured as a consequence of differences in morphological characters of plant organs.

Based on the identification, the most prominent diversity of morphological characters among locations or population within a location were leaf shape characters and length, plant height, stem colour and diameter, internode length, petiole length, and colour. Each cluster generated sub-clusters of population based on the same growth location, except cluster A. It shows that individuals from the same location or close location were clustered in proximity or a close distance. This clustering pattern suggests a closer genetic relation among the population of similar areas compared to different locations. It means that each location has unique plant characters, and therefore three populations of Aibika are indigenous in each original location. This phenomenon supports the theory that the closer the geographical areas between two individuals or population, the shorter the genetic distance between those individuals and population. However, cluster A consisted of cultivars from diverse areas, probably was due to the migration of people who brought the genetic material of Aibika from one location to another, resulting in diverse cultivars in cluster A.

The different characters of Aibika among locations were due most likely to the ecological and geographical isolation (ecogeographic). Ecogeographic isolation is induced by the external factors such us climate, water, soil and topography. These factors function as a catalyst in inducing a barrier for gene exchange among populations, and hence each population in a particular ecosystem provides unique characters in each region.

Individuals or plant populations that are separated because of ecological isolation have specific habitats and specific environments. From this point of view, succeeding populations will not be adaptive if grown in a different habitat from those of the parents. They will only grow in a similar parent habitat or in between habitats of both parent populations (Grant 1971).

Different characters among individuals in one species, apart from environmental factors or geographical isolation, are also induced by migration, mutation, and hybridization. The migration of individuals or plant populations from one continent to another, or from one location to another, and followed by geographical isolation and hybridization, may 


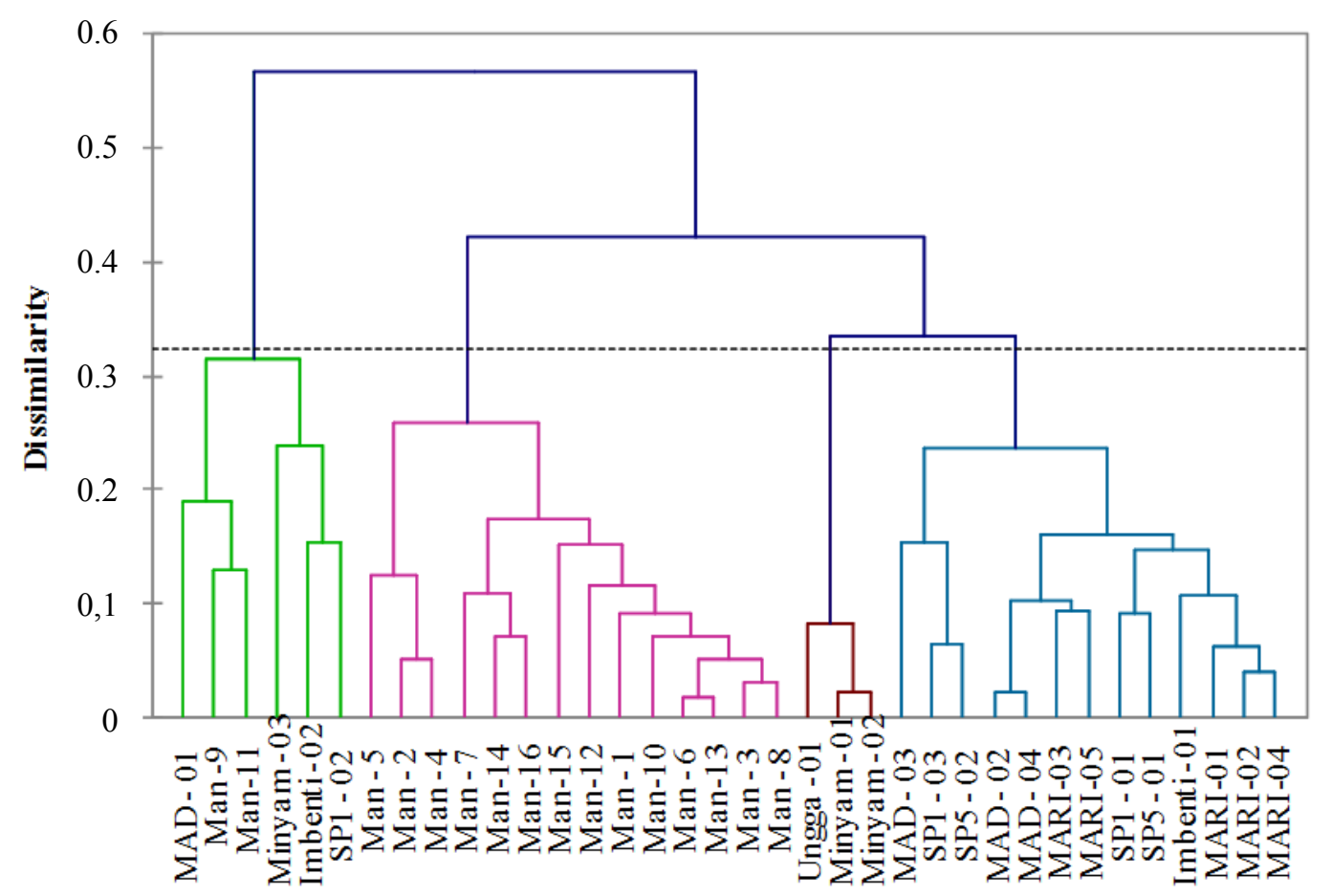

Figure 2. Dendrogram showing the dissimilarity relationship of Aibika cultivars collected from 4 different locations in Mandopi, Warmare, Prafi (lowland areas of Manokwari) and Minyambouw (the highland area of Arfak), West Papua, Indonesia

result in gene flow. Gene flow among plant populations increases the consequences of evolution and also may increase the character diversity. These create new gene combinations, raising the adaptability in location from one to other population (Nagi 1997).

\section{Traditional cultivation of Aibika}

In general, Aibika is traditionally cultivated and has not been grown in accordance with common agronomical practice. The cultivation system observed during the study consist of land clearing, preparation of planting material, planting method, maintenance, and harvesting.

Land clearing is usually carried out when farmers make a new garden, as they practise shifting cultivation. This activity is done by cooperation of the family members. The gardens which are located $2-3 \mathrm{~km}$ from their home generally belong to the family members. The field crop area is divided among members of the nuclear family or blood relatives. For field crop areas, farmers first clear grass or shrubs, then large trees are burned, which takes about 5 days for large gardens or 2-3 days for smaller gardens. The dry season is a good time to dry the remaining plants, as they will dry and decompose more quickly. Farmers believe that the ash remaining after burning increases the soil nutrient availability. When a new garden is opened, the previous land is rested (followed) after being used 3 to 4 times. Minimum tillage is practiced by Arfak people in their field crop area, where after completing burning and cleaning trees, farmers directly plant Aibika by using wooden drills. Equipment such as axes and machetes are used to cut wood and make fences. A crowbar is used to move large rocks and remnants of the roots of trees that remain in the field.

\section{Preparation of planting material}

Aibika is generally propagated using stem cuttings. Some farmers also cut old or unproductive Aibika and leave the primary stem in the field to regrow a new shoot. According to farmers, all parts of the trunk or branches can be used as planting materials, but it is best to use a stem or branch that is not too young and not too old. If the cuttings are taken from the old trunk or branch, the plant will grow slowly. The length of cuttings used by farmers is $30-40 \mathrm{~cm}$ (with 4-6 nodes). Cuttings are usually taken from the top and middle portions of healthy, mature stems. Stems are planted directly in the field. Between 2 and 3 nodes are buried, depending on the length of the cutting. The number of cutting per hole is around 3-4 cuttings. Irrigation depends on rainfall.

\section{Planting}

Aibika is cultivated in subsistence and semi-subsistence gardens. When planting time coincides with the beginning of the rainy season, Aibika growth will be faster. However, waterlogged soils will slow Aibika growth. Cultivation system practised by the local farmers in all studied locations is mixed-cropping. Aibika is commonly intercropped with some other food crops such as root crops, 


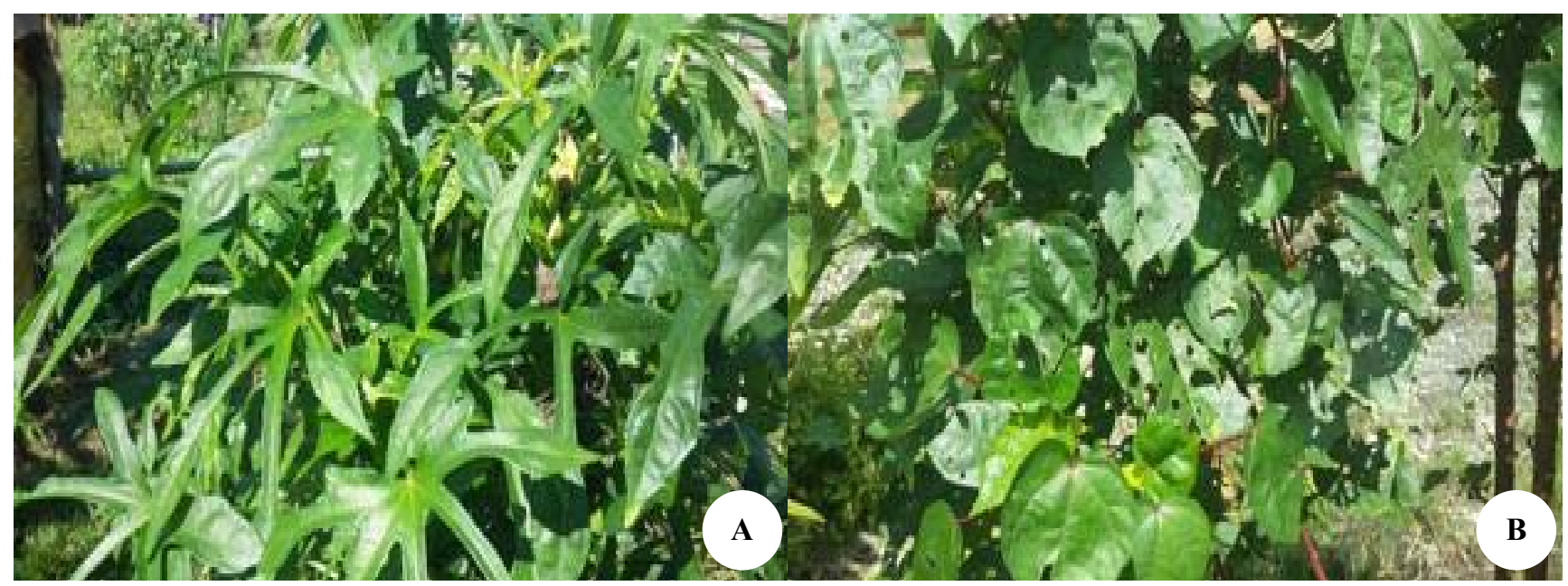

Figure 3. A. Aibika cultivars with deep lobe leaf was marketed as a leafy vegetable; B. Less marketed cultivar due to highly sap content

banana, and various vegetable crops. With a cropping pattern like this, plant spacing is not applied on a regular basis, but a few farmers use spacing of $100 \times 100 \mathrm{~cm}$ for Aibika. The tool used to make holes for planting is made from a wood stick with a length of about one metre. No fertilizer is used for improving the growth of Aibika.

\section{Maintenance}

Aibika plants are not intensively maintained after cuttings are planted. Plant maintenance is generally done earlier when the stem is newly planted. Cuttings will begin to produce shoots about two weeks after planting. Once the plants grow, farmers rarely maintain them, except for clearing grass at uncertain time intervals. Pruning is done to produce more young leaves and with an intention that Aibika plants do not grow too high to facilitate harvesting. Pruned leaves are taken for home consumption. Farmers usually only clean weeds around Aibika plants. Aibika pests that attack crops are mostly grasshoppers, caterpillars, and aphids. Grasshoppers damage the surface of the leaves while the caterpillars cause shoots to curl. The level of damage caused by pests is very high under shaded conditions and reduce the quality of Aibika leaves. Most farmers do not regularly clean up the Aibika garden to prevent pest infestation.

\section{Harvest}

Aibika plants have the advantage of being able to be grown throughout the year, and hence, it is classified as an annual plant. As stated by Goebel et al (2010), this plant can be grown all year in most tropical locations, but growth often slows with cooler, shorter days and drier conditions. Based on information from respondents, Aibika is usually first harvested at three months after planting in the lowland areas, and about six months after planting in the Arfak highland. Aibika grew in the highland generally have shorter stems, narrower leaves, shorter internodes and petiole lengths than those found in lowland locations. Aibika is generally harvested by picking young shoots and directly processing (cooked or sold in the local market). Storage for too long will cause Aibika leaves to wither and suffer damage. The productivity of Aibika plants usually declines after two years.

In conclusion, of the 39 cultivars collected from 4 areas, 16 cultivars were present in the northern part of Manokwari, West Papua. Aibika is also grown in the highland areas of Arfak as shown by the six cultivars collected from this area. Aibika traditionally cultivated in most gardens of local Papuan farmers. There is no agronomic inputs and maintenance in cultivating this plant, resulting in suboptimal growth and high susceptibility to pests. Further research is needed to develop this plant, particularly in cultivation techniques and nutritional aspects.

\section{ACKNOWLEDGEMENTS}

Thanks go to the Ministry of Research, Technology and Higher Education (Kemenristek Dikti) for funding this research through DP2M DIPA DGHE 2015, in accordance with the "grant competition scheme", with the contract number: 150/SP2H/PL/Dit.Lipabmas/II/2015. The authors also thank Indra Fernando Luhulima, Nouke Lenda Mawikere, and Ni Made Gari for their invaluable helps during the exploration and map formation.

\section{REFERENCES}

An Y, Zhang Y, Li C, Qian Q, He W, Wang T. 2011. Inhibitory effects of flavonoids from Abelmoschus manihot flowers on triglyceride accumulation in 3T3-L1 adipocytes. Fitoterapia 82: 595-600.

Goebel R, M. Taylor M, Lyons G. 2010. Leafy green vegetables in the tropics. Feasibility study on increasing the consumption of nutritionally-rich leafy vegetables by indigenous communities in 
Samoa, Solomon Islands and Northern Australia. Factsheet No. 1. The Australian Centre for International Agricultural Research (ACIAR). Canberra.

Grant, V. 1971. Plant speciation. Columbia University Press, New York.

Hodgson JM, Kevin DC. 2006. Review dietary flavonoids: effects on endothelial function and blood pressure. J Sci Food Agric 86: 24922498.

Jain PS, Bari SB, Surana SJ. 2009. Isolation of stigmasterol and (sitosterol from petroleum ether of woody stem of Abelmoschus manihot. Asian J Biol Sci 2 (4): 112-117.

Kambuou R, Paofa J, Wisnton R. 2003. Passport information and minimum descriptor list for Albika (Abelmoschus manihot L. Medik). Crop Descriptor List No. 1. National Agricultural Research Institute (NARI). Papua New Guinea.

Karafir, YP, Vokames J. 2003. Recognizing the vegetables of tebu terubuk (Saccharum edule L.) and gedi (Abelmoschus manihot) and its consumption in the food diversification of people in Nimboran district.

Prosiding Lokakarya Pangan Spesifik Lokal Papua. [Indonesian]

Kayadu N. 2013. Agroecological characterization and leaf nutrient analysis of gedi (Abelmoschus manihot L.) collected from Kemtuk and Sentani districts, Jayapura regency. Thesis. Faculty of Agriculture and Agricultural Technology, Universitas Negeri Papua, Manokwari. [Indonesian]

Lin-lin W, Xin-bo Y, Zheng-ming H, He-zhi L, Guang-xia W. 2007. In vivo and in vitro antiviral activity of hyperoside extracted from Abelmoschus manihot (L) Medik. Acta Pharmacologica Sinica 28 (3): 404-409.

Liu Y, Xianyin L, Xiaomei L, Yuying Z, Jingrong C. 2006. Interactions between thrombin with flavonoids from Abelmoschus manihot (L.) medicus by CZE. Chromatographia 64: 45, doi: 10.1365/s10337-0060841-7.

Nagy ES. 1997. Frequency-dependent seed production and hybridization rates: Implications for gene flow between locally adapted plant populatian. Evolution 51 (3): 703-714.

Preston SR. 1998. Abika / Bele. Abelmoschus manihot (L.) Medik. Promoting the conservation and use of underutilized and neglected crops. 24. Institute of Plant Genetics and Crop Plant Research, Gatersleben/International Plant Genetic Resources Institute, Rome, Italy.

Puel C, Mathey J, Kati-Coulibaly S, Davicco MJ, Lebecque P, Chanteranne B, Horcajada MN, Coxam V. 2005. Preventive effect of Abelmoschus manihot (L.) Medik on bone loss in the ovariectomised rats. J Ethnopharmacology 99: 55-60.

Shao-Yu Z, Nai-Ning S, Wen-Yuan G, Wei J, Hong-Quan D, Pei-Gen X. 2006. Progress in the treatment of chronic glomerulonephritis with traditional Chinese medicine. Asian J Pharmacodynamic Pharmacokinetic 6 (4): 317-325.

Todarwal A, Jain P, Bari S. 2011. Abelmoschus manihot Linn: ethnobotany, phytochemistry and pharmacology. Trad Med 6: 1-7.

Westwood V, Kesavan V. 1982. Traditional leafy vegetables of Papua New Guinea. Aibika (Hibiscus manihot L.). In: Bourke RM, Kesavan V (eds.). Proceeding of the Second Papua New Guinea Food Crops Conference, 1980. Part 2.

Yalambing LR, Arcot J, Greenfield H, Holford P. 2015. Aibika (Abelmoschus manihot L.): Genetic variation, morphology and relationships to micronutrient composition. Food Chem (2015). http: //dx.doi.org/10.1016/j.foodchem.2014.08.058.

Zaven, AC, Zhukovsky PM. 1980. Dictionary of Cultivated Plants and their Centres of Diversity. Pudoc, Wageningen, New York. 